\title{
Entrenching Global Governance: The EU's Constitutional Objectives Caught Between a Sanguine World View and a Daunting Reality
}

\author{
Joris Larik
}

\section{Introduction}

The international role of the EU and its contribution to global governance have become formidable topics in international relations (IR) scholarship. However, evaluations of both differ widely. One can find learned assessments concluding that the EU is indeed a superpower, ${ }^{1}$ a 'freakishly oversized "middle power", 2 or merely a small power. ${ }^{3}$ While some argue that Europe will 'run the 21 st century' equipped with its model of integration, ${ }^{4}$ others contend that it may be already 'past its peak', ${ }^{5}$ facing decline and ultimately irrelevance. ${ }^{6}$ With particular regard to global governance, there is agreement, within the liberal current of IR studies, that the EU has made an important contribution by virtue of its mere existence as a form of regional governance, ${ }^{7}$ while others, from the realist current, point to its weaknesses and dependence on external power structures. ${ }^{8}$

At the very least it can be argued that the future of the EU and its influence in the world hang in the balance. ${ }^{9}$ Either it maintains the status of 'a driving force in shaping the new rules of global governance, or risk[s] being left behind'. ${ }^{10}$ Accordingly, a multi-polar world is gradually taking shape, which might well have the effect of undoing the EU's previous successes and rise to international relevance. Events such as the sidelining of the EU at the 2009 Copenhagen Summit on climate change, the inability to find a common position on the recognition of Kosovo and Palestine or within the United Nations Security Council concerning the Libyan civil war, as well as the current debt crisis that has befallen the Eurozone, paint a rather daunting picture of things to come.

At the same time, the Lisbon Treaty, in force since 1 December 2009, has codified a range of objectives with a clear global governance dimension into the EU's primary law. Among

${ }^{1}$ J McCormick, The European Superpower (Palgrave Macmillan, 2007).

2 A Hyde-Price, 'A neurotic "centaur"-The limitations of the EU as a strategic actor' in K Engelbrekt and J Hallenberg (eds), The European Union and Strategy (Routledge, 2008) 162.

${ }^{3}$ A Toje, The European Union as a Small Power: After the Post-Cold War (Palgrave Macmillan, 2010).

4 M Leonard, Why Europe Will Run the 21st Century (Fourth Estate, 2005).

5 C Bretherton and J Vogler, 'Past Its Peak? The European Union as a Global Actor 10 Years After' in F Laursen (ed), The EU as a Foreign and Security Policy Actor (Republic of Letters, 2009).

${ }^{6}$ R Youngs, Europe's Decline and Fall: The Struggle Against Global Irrelevance (Profile Books, 2010).

7 See eg M Telò, 'Introduction: The EU as a model, a global actor and an unprecedented power' in M Telò (ed), The European Union and Global Governance (Routledge, 2009) 15. See also R Cooper, The Post-Modern State and the World Order (Demos, 2000); I Manners, 'Normative Power Europe: A Contradiction in Terms?' (2002) 40 Journal of Common Market Studies 235, 252.

8 H Bull, 'Civilian Power Europe: A Contradiction in Terms' (1982) 22 Journal of Common Market Studies 149, 151; R Kagan, Of Paradise and Power: America and Europe in the New World Order (Knopf, 2003); Hyde-Price, n 2, 156-157.

9 European Union Institute for Security Studies and the National Intelligence Council, Global Governance 2025: At a Critical Juncture (2010) 11 (Global Governance 2025).

${ }_{10}$ Project Europe 2030: Challenges and Opportunities, A report to the European Council by the Reflection Group on the Future of the EU 2030 (May 2010) 35 (Project Europe 2030). 
many other things, the Treaties now mandate the Union to expressly 'promote an international system based on stronger multilateral cooperation and good global governance. ${ }^{11}$ These objectives can be said to present the Union's constitutionally stipulated 'world view,, 12 ie the kind of world the Treaties envision and to which they mandate the Union to contribute. This introduces a manifest, but thus far rather understudied, legal dimension of global governance.

As we can see from the widely divergent assessments of the EU's role in global governance and the international system in general, which appear to 'depend quite substantially on one's views on the nature of the international system, ${ }^{13}$ there is a great need for dependable and justifiable benchmarks in this regard. It is argued here that constitutional foreign policy objectives represent an important-if not the most important-source for such benchmarks. This is so, for conceptual, empirical and normative reasons. Conceptually speaking, global governance, as commonly defined in the literature, is an inherently rule-oriented as well as goal-oriented concept. Empirically, such substantive global governance goals can be found today in many constitutions, including those of the rising powers of the emerging multipolar world. EU primary law post-Lisbon is part of this trend, but also goes further. Next to an extensive collection of substantive objectives, it also puts a distinctive emphasis on law as an essential ingredient of its foreign policy and consequently of its vision for global governance. From a normative point of view, the peculiar features pertaining to constitutional law as a source for global governance guidance, as opposed to policy documents or other law, appear at first sight as problematic. In particular for the EU, facing the challenge of 'relative decline' ${ }^{\text {'14 }}$ in a multi-polar world, entrenching such an ambitious agenda in its highest laws may appear as audacious wishful thinking. On closer inspection, however, these particular features reveal the true value of the constitutional codification of a global governance agenda.

\section{Global Governance as a Subject of Constitutional Law}

As a first step, it will be demonstrated that global governance has become a prominent theme in constitutional documents, above all in the constitutional law of the EU. Let us begin this enquiry by examining the commonly advanced definitions of global governance, which reveal that the concept is based inherently on both rules and goals.

These definitions construe global governance as rule-setting on a global scale through processes which are not in the hands of an overarching authority (as opposed to the idealized domestic setting, ie the state and its government), taking place in a multi-level environment involving a multitude of actors. ${ }^{15}$ The dynamic character of governance is already present in the term 'governance' itself, which derives from the ancient Greek word meaning 'to steer' $(\kappa v \beta \epsilon \rho v a ́ v) .{ }^{16}$ According to Rosenau, as the trailblazer on this subject, governance 'refers to mechanisms for steering social systems toward their goals' ${ }^{17}$ Most

11 Art 21(2)(h) TEU.

12 See H Kelsen, Essays in Legal and Moral Philosophy (O Weinberger ed, P Heath tr, D Reidel, 1973), ch 5 on a state's world view (Weltbild) linking its internal set-up and foreign policy. See more recently P Häberle, Verfassungslehre als Kulturwissenschaft (2nd edn, Duncker \& Humblot, 1998) 1132ff.

${ }^{13}$ K Smith, European Union Foreign Policy in a Changing World (2nd edn, Polity, 2008) 13.

14 Project Europe 2030, n 10, 11-12.

15 See the definition used by Telò, n 7, 36: 'both institutionalized and non-institutionalized, formal and informal, public and private modes of regulation and rule-setting at various levels of the globalized world'. Similarly, Global Governance 2025, n 9, 17.

16 See J Rosenau, 'Governance in the 21st Century' (1995) 1 Global Governance 13, 14.

17 J Rosenau, 'Toward an Ontology for Global Governance' in M Hewson and T Sinclair (eds), Approaches to Global Governance Theory (State University of New York Press, 1999) 296. See also earlier J Rosenau, 'Governance, order and change in world politics' in J Rosenau and E-O Czempiel, Governance without government: order and change in world politics (CUP, 1992) 4. 
telling, however, is the definition adopted by Ortega for assessing the EU's contribution to global governance, ie 'the management of global problems and the pursuit of global objectives through concerted efforts of states and other international actors' ${ }^{18}$ The crucial element here is the notion of 'global objectives'. These, according to Ortega, are the latest stage of a historical development, starting from objectives defined by each political community individually (ie the 'national interest') to the emergence of common global objectives during the course of the last century. After the end of the Cold War in particular, these have been 'growing steadily' to include such matters as the prevention of grave human rights violations, crisis and conflict management, peacekeeping, non-proliferation, and protection of the planetary environment. ${ }^{19}$

The notion of these global objectives dovetails with that of so-called 'milieu goals', defined as aims for shaping of a polity's environment, as opposed to 'possession goals', which are based on a more narrow idea of the national interest. ${ }^{20}$ Global objectives in the sense of global governance thus represent 'milieu goals' of a worldwide scope. ${ }^{21}$ Also in assessing the EU's contribution to global governance, the importance of milieu goals is acknowledged in the need 'to champion an international environment that will enable the EU to promote its agenda'. ${ }^{22}$

Such global goals, on which the idea of global governance is premised, have become a popular topic in constitutional documents, including EU primary law. Given the inclusiveness of the definition of global governance, such goals 'may or may not derive from legal and formally prescribed responsibilities'. ${ }^{23}$ However, the fact that documents codifying the highest laws of a given polity increasingly deal with such global objectives is a remarkable development and highlights a significant legal dimension to global governance which goes beyond the realm of international law. ${ }^{24}$ Mindful also of the rule-setting focus of global governance, we can distinguish two phenomena, one limited to the respective constitutional order and one transcending legal orders. The first refers to constitutionally entrenched substantive objectives relevant for global governance, such as promoting human rights, environmental protection or non-aggression. While aiming to shape the international order along certain normative lines, they leave the means to do so a priori open. The legal dimension of these thus remains contained within the respective constitutional order. The second one, on the contrary, transcends legal orders by harnessing the use of law in foreign policy. Examples for this would be promoting the rule of law internationally tout court, or more specific references to international adjudication and institutionalized international cooperation. These objectives aim to transform the international order into an increasingly rules-based system, thus linking the constitutional and the international legal orders. Where both phenomena are present, the latter also frames the pursuit of substantive goals,

${ }^{18}$ M Ortega, 'Building the future: The EU's contribution to global governance', EUISS Chaillot Paper No 100, April 2007, 46 (italics omitted).

19 Ibid 47.

20 See Smith, n 13, 8-9. She refers to the concepts as devised by A Wolfers, Discord and Collaboration: Essays on International Politics (Johns Hopkins University Press, 1962). See further on the pursuit of both possession and milieu goals by the EU the contribution by de Búrca to this volume.

${ }_{21}$ To a certain extent, the shaping of a regional milieu can also serve as a contribution to global governance. In the case of the EU, the Schuman Declaration and the founding Treaties already recognized preventing war among its Member States as also being a contribution to 'world peace'. Today, the Union has set itself the goal of establishing 'an area of prosperity and good neighbourliness' with the countries around it: Art 8(1) TEU. See further S Blockmans, 'Friend or foe? Reviewing EU relations with its neighbours post-Lisbon' in P Koutrakos (ed), The European Union's external relations a year after Lisbon, CLEER Working Paper 2011/03: <http://www.asser. nl/upload/documents/772011_51358CLEER\%20WP\%202011-3\%20-\%20KOUTRAKOS.pdf > accessed 18 March 2012 .

22 Project Europe 2030, n 10, 35.

23 Rosenau, Governance, order and change in world politics, n 17, 4.

24 Ortega points to international law sources such as Arts 1 and 2 of the United Nations Charter: Ortega, n 18, 57-58. 
mandating a polity to gearing global governance towards an order that is both more rulesbased and value-based. ${ }^{25}$ Before entering into the critical assessment of constitutional entrenchment, which will be conducted in the latter half of this chapter, an overview of the content in terms of global governance present in the EU Treaties and comparative constitutional law more generally will be provided.

\subsection{Global governance objectives in EU constitutional law}

In today's EU primary law, numerous objectives related to global governance can be found. Those include both expressions of substantive goals as well as an emphasis on law in the pursuit of these goals.

First, however, a preliminary matter needs to be addressed given the peculiar nature of the EU. The objectives codified in the original Treaties were rather the hallmark of a functional international organization. Under international law, international organizations are considered derivative legal subjects whose existence is 'entirely instrumental, directly related to the performance of certain functions'. ${ }^{26}$ Hence, at the outset European integration was better understood as an instrument of global governance among other international institutions and regimes specifically set up to pursue the goals shared by its members. However, as is widely accepted among scholars of European law, through the deepening of European integration, including the widening of the objectives, competences and fields of activity of the Union (and sustained by the progressive case-law of the European Court of Justice), EU law has acquired a quality that fits uneasily with classic international institutional law. Consequently, today the Union's primary law is predominantly considered as being of a constitutional nature, more akin to the legal order of a state than of an international organization. ${ }^{27}$ Hence, from a legal point of view it seems unwarranted to depict the EU as a mere tool of its Member States. ${ }^{28}$ Even though the Union remains an actor with only conferred powers, in view of the advanced stage European integration has reached, also in the external sphere, it is no longer a mere functional association, but rather a value-based community with an autonomous legal order. ${ }^{29}$

The Lisbon Treaty has both expanded and streamlined the Union's global objectives. The EU Treaties include now a set of general objectives of the Union, including their external dimension, ${ }^{30}$ an article containing general principles and goals of EU external action, ${ }^{31}$ and in some cases objectives specific to certain external policies. ${ }^{32}$ These principles and objectives are to be respected not only in the explicitly external Union policies, but also with regard to 'the external aspects of its other policies', ${ }^{33}$ such as environmental protection.

\footnotetext{
25 Ultimately, this would result in the 'constitutionalization' of the international legal order. No constitutional document, however, goes so far as to mandate this specifically.

${ }^{26}$ H Schermers and N Blokker, International Institutional Law (4th edn, Martinus Nijhoff, 2003) 11. See also Advisory Opinion of 8 July 1996 (Legality of the Use of Nuclear Weapons), (1996) ICJ Reps 78, para 25, in which the International Court of Justice ruled that international organizations 'are invested by the states which create them with powers, the limits of which are a function of the common interests whose promotion those states entrust to them'.

${ }^{27}$ See E Stein, 'Lawyers, Judges, and the Making of a Transnational Constitution' (1981) 75 AJIL 1; more recently P Craig, ‘Constitutions, Constitutionalism, and the European Union' (2001) 7 ELJ 125, 128-130.

${ }^{28}$ This is of course notwithstanding the criticisms of realists and liberal intergovernmentalists pointing to political realities which might suggest otherwise.

${ }_{29}$ The values are also codified: Art 2 TEU. See further A von Bogdandy, 'Founding Principles of EU Law: A Theoretical and Doctrinal Sketch' (2009) 16 ELJ 95; F Reimer, 'Ziele und Zuständigkeiten: Die Funktionen der Unionszielbestimmungen' [2003] Europarecht 992, 992-993.

${ }^{30}$ Art 3(5) TEU.

31 Art 21 TEU.

32 Arts 206 and 207 Treaty on the Functioning of the European Union (TFEU) for the Common Commercial Policy; Art 208 TFEU for development cooperation; Art 214 TFEU on humanitarian aid.

${ }^{33}$ Art 21(3), first subpar, TEU
} 
While being careful to refer also to the pursuit of 'interests', ${ }^{34}$ thus keeping the door open for the pursuit of 'possession goals', the Treaties contain a wealth of substantive objectives that squarely fall into the category of milieu goals. These include contributions to 'peace, security, the sustainable development of the Earth, solidarity and mutual respect among peoples, free and fair trade, eradication of poverty and the protection of human rights, in particular the rights of the child'. ${ }^{35}$ The Treaties also make clear that this is largely an extrapolation of the Union's internal values to the outside world. ${ }^{36}$ Nevertheless, these goals are not all autonomously defined by the Union, but are indeed open to input from external sources by drawing on internationally defined concepts such as sustainable development, universal human rights or internationally agreed goals for development cooperation. ${ }^{37}$

In addition, we find a strong emphasis on rule-of-law based goals. The various references to human rights, ${ }^{38}$ as rights, can also be seen as a matter of law. More straightforwardly, the Treaties oblige the Union to contribute 'to the strict observance and the development of international law' ${ }^{39}$ and to spread and consolidate the rule of law in the world at large. ${ }^{40}$ They furthermore identify the United Nations as the forum of choice to 'promote multilateral solutions to common problems, ${ }^{41}$ which suggests abiding by and utilizing the procedures and means provided under its Charter. Indeed, according to the Treaties, 'stronger multilateral cooperation and good global governance ${ }^{32}$ go hand in hand.

Furthermore, we also find a number of instances where the pursuit of substantive objectives is explicitly framed by law. For instance, both the Union's humanitarian aid policy and its common security and defence policy are to be carried out in accordance with the relevant international law. ${ }^{43}$ The best example for connecting and intertwining the Union and international legal orders is the obligation for the Union to accede to the European Convention for the Protection of Human Rights and Fundamental Freedoms (the Human Rights Convention) and its adjudicatory mechanism. ${ }^{44}$ In doing so the Union would not only add an additional layer to its own human rights protection, but also become a member of the international institutional framework and contribute to its further development. ${ }^{45}$

In sum, we see that the EU Treaties codify a range of global objectives both in terms of substance but also specifically harnessing law. The many substantive goals for EU external action are indeed an indication that at least constitutionally the EU is 'more inclined to try to shape its surrounding environment than to protect particular interests'. ${ }^{46}$ In addition, the Treaties also highlight the importance of law as the 'weapon of choice' ${ }^{47}$ for shaping this

\footnotetext{
34 Art 3(5) TEU, which also refers to the protection of Union citizens as an objective; also Art 21(2)(a) TEU, referring to the Union's 'fundamental interests'.

35 Art 3(5) TEU. This is reiterated and elaborated upon in Art 21 TEU and the sector-specific objectives.

${ }^{36}$ Note in particular Art 21(1) TEU: 'The Union's action on the international scene shall be guided by the principles which have inspired its own creation, development and enlargement...'.

37 See in particular Art 208(2) TFEU. See also M Cremona, 'Values in EU Foreign Policy' in M Evans and P Koutrakos (eds), Beyond the Established Legal Orders: Policy Interconnections Between the EU and the Rest of the World (Hart Publishing, 2011), who presents value formation as an iterative process between the internal and external spheres.

${ }^{38}$ Arts 3(5); 21(1), first subpara; 21(2)(b) TEU.

39 Art 3(5) TEU.

40 Arts 3(5) and 21(2)(b) TEU. See further L Pech, 'Rule of law as a guiding principle of the European Union's external action', CLEER Working Paper 2012/03: <http://www.asser.nl/upload/documents/2102012_33322cleer20123web.pdf> accessed 16 March 2012.

${ }_{41}$ Art 21(1), second subpara, TEU. See also Art 220(1) TFEU on relations of the EU with international organizations.

42 Art 21(2)(h) TEU.

43 Art 214(2) TFEU; Art 42(1) TEU.

44 Art 6(2) TEU.

45 See further J P Jacqué, 'The Accession of the European Union to the European Convention on Human Rights and Fundamental Freedoms' (2011) 48 CML Rev 995, 1008-1011.

${ }^{46}$ Smith, n 13, 9.

47 Leonard, n 4, 36.
} 
environment accordingly. Together, these elements coincide with the idea of the Union as a 'transformative power', changing not only fundamentally the relations among its members but also of the world around it. ${ }^{48}$ As Manners famously put it, the EU aims at 'redefining what can be "normal" international relations'. ${ }^{49}$ The norms contained in the EU Treaties constitutionally entrench not only a vision of global governance based on certain values, but also based on legal rules and institutions.

\subsection{Global governance and the global 'dynamization of constitutional law'}

One can observe a general trend in modern comparative constitutional law to introduce internationally oriented objectives to guide a country's foreign policy. ${ }^{50}$ In view of the content of these objectives, it cannot be denied that global governance has become a theme of contemporary constitutional law. Due to space constraints, here only a few examples from national constitutions will be provided, ${ }^{51}$ distinguishing again between substantive constitutional objectives and those relying specifically on law. Next to examples of constitutions of EU Member States, which are rather extensive in this regard, the constitutions of the four BRIC countries (Brazil, Russia, India, China) will be considered. ${ }^{52}$ This seems warranted given the attention devoted to these rising actors and the prospect of a multi-polar world in the IR literature, which is presented as one of the major challenges for the EU. ${ }^{53}$

Among the EU Member States, the cases of Ireland and Portugal stand out. The Irish constitution includes an article on the international relations of the country. In terms of substance, it refers to Ireland's 'devotion to the ideal of peace and friendly co-operation amongst nations founded on international justice and morality'. ${ }^{54}$ The international legal dimension becomes apparent in 'its adherence to the principle of the pacific settlement of international disputes by international arbitration or judicial determination', ${ }^{55}$ as well as in its acceptance of international law 'as its rule of conduct in its relations with other States' ${ }^{56}$

A similar but more verbose statement can be found among the seven paragraphs of a long article in the constitution of Portugal. In terms of substance, it states that Portugal's international relations are to be governed by 'the peaceful settlement of international disputes, the non-interference in the internal affairs of other states and cooperation with all other peoples for the emancipation and progress of humanity'. ${ }^{57}$ In terms of law as a

48 Ibid 5

49 Manners, n 7, 253.

$50 \mathrm{~J}$ Larik, 'Shaping the International Order as a Union Objective and the Dynamic Internationalization of Constitutional Law', CLEER Working Paper 2011/05: <http://www.asser.nl/upload/documents/ 11222011_91506CLEER\%20WP\%202011-5-LARIK.pdf> accessed 16 March 2012.

51 The references to national constitutions in their English language translations draw on the Oceana Law database 'Constitutions of Countries of the World': <www.oceanalaw.com> accessed 19 March 2012.

52 The constitution of the most powerful country in the world, the USA, does not contain any objectives relevant for global governance, which may be explained by its age and the few amendments it has undergone. Nevertheless, American foreign policy has long been recognized as 'exceptional' and reflecting its internal values and institutional preferences. See A Bradford and E Posner, 'Universal Exceptionalism in International Law' (2011) 52 Harv ILJ 3, 35-44, who argue that this applies to most other great powers as well.

${ }^{53}$ See eg Project Europe 2030, n 10, 12; Global Governance 2025, n 9, 25-30. See in detail S Keukeleire and H Bruyninckx, 'The European Union, the BRICs and the Emerging New World Order' in C Hill and M Smith (eds), International Relations and the European Union (2nd edn, OUP, 2011).

${ }_{54}$ Art 29(1) Irish constitution. See further G Hogan and G Whyte, J.M. Kelly: The Irish Constitution (4th edn, LexisNexis, 2003) 491-506.

55 Art 29(2) Irish constitution.

56 Art 29(3) Irish constitution. Note also the constitutional authorization to ratify the Rome Statute of the International Criminal Court (ICC) in Art 29(9).

57 Art 7(1) Portuguese constitution. See also Art 7(2) for more historically rooted goals (eg 'dissolution of the political-military blocs'). Note furthermore the mandate for privileged cooperation with Portuguese-speaking countries in Art 7(4). See further P J Canelas de Castro, 'Portugal's World Outlook in the Constitution of 1976' (1995) 71 Boletim da Faculdade de Dereito da Universidade de Coimbra 489. 
foreign policy tool, it has less to offer. Still this dimension is present in its references to certain 'rights', which next to human rights and 'the rights of peoples ${ }^{58}$ include 'the right of peoples to self-determination, independence and development, as well as the right of insurrection against all forms of oppression.. 59 Similarly, the specific provision allowing the country to join the International Criminal Court (ICC) Statute is premised on 'achieving an international justice that promotes respect for the rights of the human person and of peoples' ${ }^{60}$

The trend of including a global governance agenda into constitutional documents is by no means confined to Europe. As we shall see, three of the four BRIC countries also devote constitutional language to how their countries will contribute to global governance. The Russian constitution, apart from asserting consciousness 'that we are part of the world community', ${ }^{61}$ does not contain normative guidance in terms of foreign policy. The case is different with Brazil, China and India. However, while all three contain objectives relevant for global governance in terms of substance, only the Indian constitution puts a comparable emphasis on law.

The constitution of Brazil contains a title on 'fundamental principles' ${ }^{\prime 2}$ according to which Brazil's international relations are governed, among other things, by the principles of 'prevalence of human rights', ${ }^{63}$ 'non-intervention', 'p4 'pacific solution of conflicts' ${ }^{65}$ and 'repudiation of terrorism and racism'. ${ }^{66}$ The legal dimension is less explicit. Next to the reference to human rights, it could be gleaned from the reference to the 'self-determination of peoples', 67 albeit not framed as a right under international law. Moreover, the sole paragraph of this article makes regional integration in Latin America a constitutional objective, ${ }^{68}$ which might also imply a stronger rules-based regional community.

The most verbose among the BRIC countries, at least in terms of substance, is the constitution of the People's Republic of China. ${ }^{69}$ In its preamble, it is stressed that the 'future of China is closely linked with that of the whole world'. ${ }^{70}$ Moreover, in terms of what guides China's global role, the preamble evokes:

'the five principles of mutual respect for sovereignty and territorial integrity, mutual nonaggression, non-interference in each other's internal affairs, equality and mutual benefit, and peaceful coexistence in developing diplomatic relations and economic and cultural exchanges with other countries' ${ }^{71}$

In addition, it contains what can be seen as a clear example of a possession goal, ie 'the great task of reunifying the motherland' with Taiwan. ${ }^{72}$ Even though construed as a domestic

58 Art 7(1) Portuguese constitution.

59 Art 7(3) Portuguese constitution.

60 Art 7(7) Portuguese constitution.

61 Preamble, Russian constitution.

${ }^{62}$ See M Gonçalves Ferreira Filho, 'Fundamental Aspects of the 1988 Constitution' in J Dolinger and K Rosenn, A Panorama of Brazilian Law (North-South Center and Editora Esplanada, 1992) 13-15.

63 Art 4(II) Brazilian constitution.

${ }^{64}$ Art 4(IV) Brazilian constitution.

65 Art 4(VII) Brazilian constitution.

66 Art 4(VIII) Brazilian constitution

67 Art 4(III) Brazilian constitution.

68 Art 4 Brazilian constitution.

69 The lack of judicial review and 'constitutionalism' in general in the People's Republic, however, qualify the importance of the text of its constitution. See Q Zhang, 'A constitution without constitutionalism? The paths of constitutional development in China' (2010) 8 ICON 950.

${ }^{70}$ Preamble, Chinese constitution.

71 Preamble, Chinese constitution, which furthermore refers to opposition to imperialism, hegemonism and colonialism' and support for developing countries. The 'five principles' were first listed in an international agreement between China and India in 1954 and have since been an essential part of Chinese foreign policy. See Bradford and Posner, n 52, 26.

${ }^{72}$ Preamble, Chinese constitution. It should be noted that 'reunification' is also a topic, for instance, in the Irish constitution. The latter, however, expressly states 'that a united Ireland shall be brought about only by peaceful 
issue, its international ramifications are undeniable. The Chinese constitution does not address law as a defining factor of its foreign policy. At most, one could see the five principles as a reflection of a traditional Westphalian view of international law.

The picture is different with the Indian constitution and its list of 'directive principles of state policy'. ${ }^{73}$ While the constitution states that these principles are non-enforceable in court, they are 'nevertheless fundamental in the governance of the country'. ${ }^{74}$ It contains four principles concerning India's foreign policy. The first two are of a substantive character, obliging the state to endeavour to 'promote international peace and security ${ }^{75}$ and to 'maintain just and honourable relations between nations' ${ }^{76}$ The latter two put the emphasis on law, much like the Irish constitution. ${ }^{77}$ They mandate the state to 'foster respect for international law and treaty obligations in the dealings of organized peoples with one another ${ }^{178}$ and to 'encourage settlement of international disputes by arbitration. ${ }^{79}$

In sum, we see that global governance is a common theme in contemporary constitutions, including those of the rising powers, which are regularly portrayed as a threat to global governance, bringing 'with them their own vision of the world, which can differ considerably from that of the established ones' ${ }^{80}$ Looking at their highest laws, however, paints a less threatening picture. Evidentially, the preamble of the Chinese constitution with its emphasis on non-interference and sovereignty conveys a more traditional, static image of the international order. This leaves less scope for wide-ranging and ambitious international regulation and powerful institutions. ${ }^{81}$ Nevertheless, these objectives all represent milieu rather than possession goals. Leaving China aside, the fact that substantive norms such as human rights are constitutionally entrenched as guiding principles for foreign policy is remarkable. Compared to the comprehensive objectives provided in the EU Treaties, however, the national constitutions examined here give rather sporadic guidance.Concerning the role of law within global governance, we also see a number of national constitutional pronouncements, but markedly fewer. The explicit emphasis and many linkages made between law and the pursuit of substantive objectives in the EU Treaties is not matched in these national constitutions. From the vantage point of constitutional law, we find thus that EU foreign policy represents not only 'a reflection of the global zeitgeist', ${ }^{82}$ but goes further given both the comprehensiveness in terms of substance and the special emphasis placed on law for the shaping of global governance.

\section{Entrenched Global Governance: A Blessing in Disguise}

Global governance, by definition heavily reliant on both rules and goals, is addressed in contemporary constitutional documents, above all those of the EU. But why should we, when studying global governance and the EU, pay special attention to objectives found in its constitutional law as opposed to foreign policy documents such as the European Security

means with the consent of a majority of the people, democratically expressed, in both jurisdictions in the island', Art 3(1) Irish constitution.

73 See O Chinnappa Reddy, The Court and the Constitution of India: Summits and Shallows (OUP, 2008), ch 9.

74 Art 37 Indian constitution.

75 Art 51(a) Indian constitution.

76 Art 51(b) Indian constitution.

77 The Indian 'directive principles' have in fact drawn inspiration from the Irish constitution. See J Usman,

'Non-Justiciable Directive Principles: A Constitutional Design Effect' (2007) 15 Mich St JIL 643, 650-651.

${ }^{78}$ Art 51(c) Indian constitution.

79 Art 51(d) Indian constitution.

80 The New Global Puzzle: What World for the EU in 2025 (EUISS, 2006) 195 (The New Global Puzzle).

81 Even though not constitutionally stated, the same could be said about US foreign policy, but for the different reason of alleged aversion to deferring to 'political and bureaucratic elites' both domestically and internationally. Bradford and Posner, n 52, 42.

${ }^{82}$ Smith, $\mathrm{n} \mathrm{13,} 231$ (italics in the original). 
Strategy? ${ }^{83}$ Recalling Rosenau's definition, global governance goals must not necessarily be legal in nature, and 'include systems of rules at all levels of human activity-from the family to the international organization'. ${ }^{84}$ This notwithstanding, the constitution stands out among these sources as the supreme legally entrenched document organizing a political community into a normative order endowed with institutions to uphold that order and pursue collective goals. ${ }^{85}$ Hence, constitutions cover and consolidate a considerable part of 'rules at all levels of human activity' to an extent that hardly any other document could offer.

Consequently, constitutional objectives also distinguish themselves from goals of day-today foreign policy. Unlike policy goals, they have been adopted through a legislative procedure. As legal norms, they are in principle justiciable. ${ }^{86}$ They are part of a 'stable framework' meant to 'preserve stability and continuity in the legal and political structure, and the basic principles that guide its institutions' ${ }^{87}$ Once adopted, they are entrenched, ie more difficult to alter than ordinary legislation, ${ }^{88}$ or a fortiori government policy. In the case of the EU, amendments are particularly challenging, as the failure of the Constitutional Treaty and the delayed ratification of the Lisbon Treaty have shown.

Entrenchment poses three main challenges: First, constitutionally codifying a particular vision of global governance may lead to an excessive 'judicialization of politics'; secondly, such objectives are prone to raising unrealistic expectations; and thirdly, it may be undemocratic to lock in place the global governance agenda of a given political community in a fastchanging world. It will be argued here that these challenges ultimately reveal the true merit of the constitutional objectives of the EU and other major powers as a source of guidance for global governance.

\subsection{Judicialization of foreign policy—or readjusting the institutional balance}

Since these objectives concern foreign policy, the first question that arises is the extent to which constitutional codification constitutes an excessive legalization of foreign policy, especially when this is done in a rather detailed and rule-of-law based fashion, such as in the EU. This in turn also suggests a stronger involvement of the judiciary and especially constitutional courts mandated to interpret the constitution and detect instances where it has been violated. ${ }^{89}$ In national settings, constitutional objectives have been criticized for potentially restricting the discretion of the political branches, which would be subject to the

\footnotetext{
${ }^{83}$ European Council, A Secure Europe in a Better World, European Security Strategy (12 December 2003).

84 Rosenau, 'Governance in the Twenty-first Century', n 16, 13.

85 This draws on J Raz's concept of a 'thick constitution'. J Raz, 'On the Authority and Interpretation of Constitutions: Some Preliminaries' in L Alexander (ed), Constitutionalism: Philosophical Foundations (CUP, 1998) 153. See also with regard to the EU, Craig, n 27, 126-127. As we have seen in the case of the EU, it is not only states that can have constitutions. Even though constitutionalism on a global scale is 'thinner' than at the state or EU level, it is more a question of degree than one of a categorical kind. See M Kumm, 'The Cosmopolitan Turn in Constitutionalism: On the Relationship Between National Constitutional Law and Constitutionalism beyond the State' in J Dunoff and J Trachtman (eds), Ruling the World? Constitutionalism, International Law, and Global Governance (CUP, 2009).

${ }^{86}$ Specifically on EU objectives, Reimer, n 29, 1000; C Calliess, 'Kollektive Ziele und Prinzipien im Verfassungsrecht der EU-Bestandsaufnahme, Wirkungen und Perspektiven' in C Hiebaum and P Koller (eds), Politische Ziele und juristische Argumentation (Franz Steiner, 2003) 90-93.

${ }_{87}$ Raz, n 85, 153.

88 Ibid.

${ }^{89}$ In addition, a foreign policy relying heavily on international legal commitments raises the question of the domestic status of international law. Once introduced into the domestic legal order, even though usually at subconstitutional level, the courts are also called upon to interpret and apply it. See on this perennial question in the EU context, for instance, the various contributions in E Cannizzaro, P Palchetti and R Wessel (eds), International Law as Law of the European Union (Martinus Nijhoff, 2012).
} 
ultimate say of a 'government of judges' (gouvernement des juges), ${ }^{90}$ turning the former into mere 'executors of state objectives' (Staatsziel Vollstrecker). ${ }^{91}$

This would appear to apply a fortiori to foreign affairs. The traditional view is that in this domain the executive has to act strongly and promptly, leaving only a very limited or nonexistent role for the judiciary, ${ }^{92}$ a view that is 'premised on the existence of dangers in the wider world that have long been banished at home'. ${ }^{93}$ This resonates with the criticisms

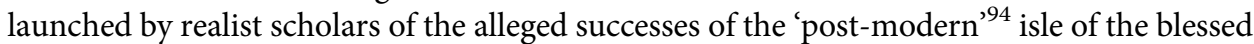
created through European integration, the success of which was only possible due to favourable power structures. ${ }^{95}$ Whether Europe's model can thus be exported externally, or can at least be preserved in the multi-polar world, is highly questionable from this point of view. This in turn creates tension between the uncertainties pertaining to foreign affairs, which require a free rein for the executive, and the interpretation and application of the constitution, including its ambitious foreign policy objectives, which is incumbent upon the judiciary.

However, this criticism is unwarranted when the wording and particular legal features of constitutional objectives in general, and foreign policy objectives in particular, are taken into account. Although they are in principle justiciable, the scope of their obligation extends to their active pursuit, allowing for various courses of action. ${ }^{96}$ Only manifest disregard of an objective would qualify as a constitutional infringement. Consequently, courts usually accord great discretion to the government in pursuing foreign policy. ${ }^{97}$ An illustration for this is the Racke case before the Court of Justice of the EU (CJEU), in which the Court limited itself to assessing whether the Council had committed 'manifest errors of assessment', of which it found none. ${ }^{98}$ The Council's reliance on the rebus sic stantibus principle was debatable, not least in view of what the Treaty on European Union (TEU) now calls the 'strict compliance with international law', but hinged on granting the political branches the appropriate leeway, also in view of other objectives such as international peace and security. Moreover, the EU Treaties offer a distinction in terms of legal scrutiny, largely excluding the CJEU's jurisdiction from the Common Foreign and Security Policy (CFSP) but not from other policies. ${ }^{99}$ The Treaties thus recognize that in certain cases the rule of law may have to take a back seat, but also circumscribe the scope of this reduced scrutiny lest it spill over into other areas where it would not be necessary. ${ }^{100}$

Moreover, constitutional objectives can only be pursued within the bounds of what is feasible. ${ }^{101}$ In this sense, the objectives of the EU, too, are rather defined as superior

90 P De Montalivet, Les objectifs de valeur constitutionnelle (Dalloz, 2006) 64, referring to the French legal discourse, but rejecting this criticism.

91 From the German point of view, D Merten, 'Über Staatsziele’ [1993] Die Öffentliche Verwaltung 368, 376; J Isensee, 'Staatsaufgaben' in J Isensee and P Kirchhof (eds), Handbuch des Staatsrechts der Bundesrepublik Deutschland, vol 4 (3rd edn, CF Mülller, 2010) 144.

${ }_{92}$ T Franck, Political Questions/Judicial Answers: Does the rule of law apply to foreign affairs? (Princeton University Press, 1992) 14. See also D Thym, 'Foreign Affairs' in A von Bogdandy and J Bast (eds), Principles of European Constitutional Law (2nd edn, Hart Publishing/CH Beck, 2011) 311-314 on the particularity of foreign policy in the EU legal order.

93 A-M Slaughter Burley, 'Are Foreign Affairs Different?' (1993) 106 Harv L Rev 1980, 1981.

94 The term was coined by Cooper, $\mathrm{n} 7$.

95 See eg Bull, n 8, 151; Hyde-Price, n 2, 156-157; Kagan, n 8.

96 On the intricacies of choosing between addressing a problem first through an internal or external lawmaking venue, see the contribution by De Witte and Thies to this volume.

97 Larik, n 50.

98 Case C-162/96 Racke [1998] ECR I-03655, paras 52-60. See also Case 112/80 Dürbeck [1981] ECR 01095, para 44 .

99 Art 24(1), second subpara, TEU and Art 275 TFEU. See also Thym, n 92, 326-330.

100 Art 40 TEU. The CJEU has exercised its jurisdiction to patrol this dividing line. See B Van Vooren, 'The Small Arms Judgment in an Age of Constitutional Turmoil' (2009) 14 EFA Rev 231.

101 See K-P Sommermann, Staatsziele und Staatszielbestimmungen (Mohr Siebeck, 1997) 224, arguing principally from the German perspective. 
mandates for action, which, instead of being entirely achieved, can only be approximated. ${ }^{102}$ In external affairs, this approximation becomes a crucial qualification, as it requires the consideration of not just the internal political and material constraints, but also those beyond one's own borders. A more practical function of foreign policy objectives hence resides in the interpretation of other constitutional norms in their light, rather than their strict enforcement through courts. ${ }^{103}$

Hence, the actual 'judicialization', ie the extent to which the political branches responsible for the conduct of foreign policy will be held accountable by the courts, is fairly limited. Nevertheless, there is merit in the fact that the judiciary is not entirely excluded. If nothing else, courts serve as the last instance to ensure that the codified goals relevant for global governance are not completely disregarded and factor into the overall interpretation of the constitution. In this way, instead of being distorted, the institutional balance, which is a fundamental principle of EU law, ${ }^{104}$ is restored and the rule of law extended further into the area of external relations. This would seem particularly important for the EU as a 'Community based on the rule of law' ${ }^{105}$ and whose external action is to 'be guided by the principles which have inspired its own creation', ${ }^{106}$ which include this very rule of law. ${ }^{107}$ For the sake of credibility these principles should not cease to apply 'at the water's edge ${ }^{\text {'108 }}$ before its own courts. Also from a global governance perspective, in which an entirely 'free hand' of the executive in foreign policy seems increasingly misplaced and other branches of government (as well as non-governmental actors) need to be included in the process, this would only seem appropriate.

\subsection{Raising unrealistic expectations-or fostering multilateral solutions}

Beyond the involvement of the judiciary, another major criticism to which constitutional foreign policy objectives are prone to be subjected is that of raising unrealistic expectations that will be virtually impossible to satisfy in view of the immense challenges that global governance faces.

Constitutional objectives in national law and EU law have already been castigated for being unrealistic in general. Instead of dependable legal guarantees that can be invoked in court, codified objectives would serve merely to draw up 'political utopias ${ }^{\text {'109 }}$ or represent not more than 'a dustbin of sentiment'. ${ }^{110}$ This concerns also so-called 'social rights' such as the right to housing or work. At worst, these objectives might eventually question the very 'effectiveness of constitutional law' (Leistungsfähigkeit des Verfassungsrechts). ${ }^{111}$ Similar criticisms have been voiced with regard to the EU and its manifold codified objectives, which have been called, for example, a 'Christmas tree'112 and a

\footnotetext{
102 See M Kotzur, 'Die Ziele der Union: Verfassungsidentität und Gemeinschaftsidee' [2005] Die Öffentliche Verwaltung 313, 315.

103 Reimer, n 29, 1000-1005; Calliess, n 86, 92.

104 See eg K Lenaerts and P Van Nuffel, European Union Law (3rd edn, Sweet \& Maxwell, 2011) 635-636.

105 Case 294/83 Les Verts [1986] ECR 01339, para 23.

106 Art 21(1), first subpara, TEU.

107 The rule of law also appears among the values of the Union, Art 2 TEU. See also Art 21(2)(b) TEU, which states the external consolidation of the rule of law as an explicit objective.

${ }^{108} \mathrm{P}$ Eeckhout, Does Europe's Constitution Stop at the Water's Edge? Law and Policy in the EU's External Relations (Europa Law, 2005).

${ }^{109}$ Isensee, n 91, 144, on German constitutional objectives. See also Merten, n 91, 373.

110 This quote stems from T T Krishnamachari, who used it to describe the Indian 'directive principles', cited in Usman, n 77, 651 .

${ }^{111}$ P Badura, 'Arten der Verfassungsrechtssätze' in J Isensee and P Kirchhof (eds), Handbuch des Staatsrechts der Bundesrepublik Deutschland, vol 8 (1st edn, CF Müller, 1992) 41.

${ }^{112}$ F-X Priollaud and D Siritzky, Le Traité de Lisbonne: Texte et commentaire article par article des nouveaux traités Européens (TUE-TFUE) (La Documentation Française, 2008) 35-36, attributing this image to the British delegation at the 2002-2003 Convention on the Future of Europe.
} 
'hodgepodge'. ${ }^{113}$ This criticism would apply a fortiori to the domain of external relations of the EU and other countries that have included ambitious external objectives in their constitutions. This is already reflected in such commentaries describing them as 'redolent of motherhood and apple pie'114 or as a 'wish list for a better world' (Wunschzettel für eine bessere Welt). ${ }^{115}$

Consequently, the codification of such a 'wish list' in a place as prominent as the constitutional charter would likely serve to widen further the Union's infamous 'capabilitiesexpectations gap'. ${ }^{116}$ The contrast between ambition and reality is bound to become even sharper over the next decades, at least according to the more dire forecasts on the future of global governance and the international role of the EU. What is generally observed is the 'relative decline' of European power and influence in a changing world, ${ }^{117}$ for instance through a diminishing share in global wealth ${ }^{118}$ and population. ${ }^{119}$ At the same time, global problems such as climate change, increased energy consumption and proliferation of weapons of mass destruction, among other things, loom large, ${ }^{120}$ making the world of tomorrow 'a far less hospitable place'. ${ }^{121}$

Against this backdrop, the EU can be seen as 'flirting rather dangerously with failure and irrelevance, ${ }^{122}$ while its constitution stipulates, among many other things, to do nothing less than to help eradicate poverty in the world, ${ }^{123}$ integrate all countries into the world economy, ${ }^{124}$ and 'develop international measures to preserve and improve the quality of the environment and the sustainable management of global natural resources'. ${ }^{125}$ The combination of ambitious goals and limiting capacities may well provide 'a recipe for disappointment'. ${ }^{126}$ This is especially true when such ambitions are entrenched in a constitutional document.

However, not all accounts of the future are equally bleak. Despite relative decline and mounting challenges, it is asserted that in '2025, the EU is likely to be still one of the richest and safest parts of the world', ${ }^{127}$ retaining its status as the world's second superpower 'for a generation or more'. ${ }^{28}$ Therefore, these objectives, even though ambitious, are not entirely unrealistic. Given that the EU will still have considerable capabilities and assets at its disposal, it will be able to continue to actively pursue these goals.

Crucially, the main challenges of global governance are typically beyond the powers of any single state or regional bloc such as the EU. This is most obvious in cases where so-called 'global public goods' are at stake, such as international security and or a healthy global environment. These problems will be solved only by a concerted effort on a global scale

113 A von Bogdandy, 'The European constitution and the European identity: Text and subtext of the Treaty establishing a Constitution for Europe' (2005) 3 ICON 295, 315, commenting on the failed Constitutional Treaty.

114 A Dashwood and others, Wyatt and Dashwood's European Union Law (6th edn, Hart Publishing, 2011) 903.

115 W Drescher, 'Ziele und Zuständigkeiten' in A Marchetti and C Demesmay (eds), Der Vertrag von Lissabon: Analyse und Bewertung (Nomos, 2010) 68.

${ }^{116}$ C Hill, 'The Capability-Expectations Gap, or Conceptualising Europe's International Role' (1993) 31 Journal of Common Market Studies 305.

117 Project Europe 2030, n 10, 11-12.

118 Youngs, n 6, 7.

119 Telò, $\mathrm{n} 7,15$.

120 Project Europe 2030, n 10, 12; Ortega, n 18, 35-40.

121 The New Global Puzzle, n 80, 199. See also Telò, n 7, 20, who speaks of an emerging 'globalization malaise'.

122 Smith, n 13, 240.

123 This goal is codified three times in the Treaties: Art 3(5) TEU; Art 21(2)(d) TEU; and Art 208(1), second subpara, TFEU.

124 Art 21(2)(h) TEU; also Art 208(1), second subpara, TFEU.

125 Art 21(2)(f) TEU.

126 Project Europe 2030, n 10, 5.

127 The New Global Puzzle, n 80, 203.

128 A Moracvcsik, 'Why the "Second Superpower" Needs a New Discourse', EUI RSCAS Policy Paper 2011/01, 43: <http://cadmus.eui.eu/bitstream/handle/1814/16356/RSCAS_PP_2011_01.rev.pdf?sequence $=4>$ accessed 18 March 2012. See also Leonard, n 4, 8, who even speaks of a 'New European Century'. 
involving a plurality of actors. Therefore, the stress the EU Treaties put on the 'governance mode of foreign policy,, ${ }^{129}$ ie 'multilateral solutions to common problems'130 and the furthering of 'an international system based on stronger multilateral cooperation and good global governance ${ }^{131}$ is of crucial significance. Combined with the fact that, albeit to a lesser degree, multilateral cooperation based on certain common principles is also reflected in the constitutions of other major powers, it bolsters the claim that the EU 'would thus act not only by defending the interest of its near 500 million citizens, but also the interests of its 500 million neighbors and even the 6.5 billion inhabitants of the planet'. ${ }^{132}$ Since international cooperation is enshrined in many constitutions today, one may even go as far as to speak of a global 'duty of sincere cooperation', ${ }^{133}$ with its basis in national or supranational constitutional law. This does not mean that multilateral solutions including legally binding commitments have to be pursued all the time and at all cost. ${ }^{134}$ Nevertheless, as we have seen, rules-based solutions within the 'governance mode' doubtlessly enjoy a preference in the EU Treaties. Contrary to any false expectations to single-handedly solving the Herculean tasks facing international society, it is the EU's own experience as a multilateral arrangement based on the rule of law which makes it pre-destined to play a role in co-leadership of multilateral efforts. ${ }^{135}$

\subsection{Undemocratic - or the people's call for global governance}

The third major criticism that could be launched against constitutional foreign policy objectives, in particular those of the EU, would be that they are undemocratic or countermajoritarian. Through constitutional entrenchment, certain matters are 'taken off the agenda of normal politics' ${ }^{136}$ This would also apply to entrenching into the constitution a particular vision of global governance that the polity is obliged to pursue, unless and until it is changed through a burdensome amendment procedure. Consequently, the kind of global governance to which the EU will contribute is to a certain extent pre-determined and cannot be changed easily. ${ }^{137}$ The EU already suffers from a 'democracy deficit', ${ }^{138}$ which would be extended to the external sphere. In terms of a two-level game, ${ }^{139}$ this means the possible overlap with other parties and stakeholders of agreeable solutions at the international level is structurally constrained.

But as we have seen, these objectives are neither excessively constraining nor entirely unrealistic, even though EU constitutional law goes further than that of most countries. This means that in the pursuit of these objectives, the political branches possess an ample measure of discretion. Whereas the basic parameters are fixed, whoever is in power in the EU can exercise their competence in external relations as long as constitutional objectives are not manifestly disregarded. Furthermore, as the Lisbon Treaty has expanded the powers

\footnotetext{
129 To use the term devised by de Búrca in her contribution to this volume.

130 Art 21(1), second subpara, TEU.

131 Art 21(2)(h) TEU.

132 Telò, $n$ 7, 26.

133 Akin to the duty existent already within the EU, Art 4(3) TEU.

134 As the respective contributions by Marín Durán, Morgera, and Scott and Rajamani to this volume show, the same substantive environmental objectives can be pursued through various means, ranging from multilateral treaties to unilateral measures.

135 Telò, n 7, 26.

136 Craig, n 27, 126.

137 This may lead the way to the 'dead hand of the past' criticism of constitutional law in general, which questions the constitutional authority that over time becomes detached from its original authors, Raz, $\mathrm{n} 85$, 164-169. See also Usman, $n$ 77, who sees Indian 'directive principles' as problematic principally for this reason.

${ }_{138}$ See eg Lenaerts and Van Nuffel, n 104, 741-742.

139 See R Putnam, 'Diplomacy and Domestic Politics: The Logic of Two-Level Games' (1988) 42 International Organization 427. Of course, this can sometimes be used as a bargaining device.
} 
of the European Parliament in the area of external relations, ${ }^{140}$ the democratic deficit is somewhat lessened by introducing another institution that can rely on Treaty objectives in scrutinizing the performance of the Council and Commission. In addition, it can give its own-democratically legitimized-interpretations of the objectives in a 'heterarchical' setting involving all constitutional branches. ${ }^{141}$

Apart from that, it can be argued that contents codified and entrenched into a constitutional document enjoy a considerable amount of inherent legitimacy. ${ }^{142}$ This actually represents the most important merit of constitutional objectives relevant for global governance. It becomes evident when we consider the " global governance dilemma", whereby the more global regulation is needed and implemented, the more demands are necessarily going to rise from the bottom up for democratic legitimacy and accountability of decisionmakers. ${ }^{143}$ One could thus speak of a global 'democracy deficit' caused by expanding global governance needs.

Constitutional documents would be able to provide such legitimacy. Instead of referring to mere policy documents, decision-makers can point to the democratically established highest laws of their respective political communities to justify their actions with a global governance dimension. This relates, to draw again on Raz's concept of thick constitutionalism, to the aspect of a constitution as 'common ideology', ie principles

that are generally held to express the common beliefs of the population about the way their society should be governed. It serves, you may say, not only as a lawyers' law, but as the people's law. Its main provisions are generally known, command general consent, are held to be the (or part of the) common ideology that governs public life in that country. ${ }^{144}$

Through the insertion of foreign policy objectives, this 'common ideology' has now acquired an external dimension. It is no longer merely the expression of the people as to how 'their society' within the confines of its borders is to be governed, it also expresses the core principles of how this community is to shape the international order. Otherwise put, it lays down the people's preferences, in their capacity as constitutional legislator or pouvoir constituant, for a particular vision of global governance itself.

Being able to point to this factor is not to be underestimated in terms of legitimacy as 'the hard currency of future international relations ${ }^{\text {'145 }}$ and 'a central component of power, or the ability to achieve appointed goals'. ${ }^{146}$ Also here, the EU finds itself in the vanguard. Having established the first transnational democratic system, ${ }^{147}$ its constitution can be seen as the expression not simply of one people but of the numerous peoples united within the Union. The fact that the EU Treaties have not been voted upon in a direct referendum does not change this. ${ }^{148}$ After all, the democratically chosen representatives in the 27 EU Member

140 Notably, the European Parliament's consent is now required for a wide range of international agreements, including in the area of trade, which was previously not the case, Art 218(6)(a) TFEU; Art 207 TFEU. See further $\mathrm{R}$ Passos, 'The European Union's external relations a year after Lisbon: a first evaluation from the European Parliament' in Koutrakos, n 21.

${ }^{141}$ See D Halberstam, 'Constitutional Heterarchy: The Centrality of Conflict in the United States and Europe' in Dunoff and Trachtman (eds), n 85, who argues that all three branches have a role in constitutional interpretation based on their expertise, capacity to represent the people and ability to protect individual rights.

${ }_{142}$ This applies of course to constitutions that have been adopted democratically or have come to be accepted and applied in a democratic system and not those situated in a very 'thin' constitutional context.

143 Telò, n 7, 19.

144 Raz, n 85, 153-154.

145 The New Global Puzzle, n 80, 198.

146 Ibid. See also Telò, n 7, 34 .

${ }^{147} \mathrm{~J}$ Hoeksma, 'The EU as a democratic polity in international law', CLEER Working Paper 2011/2: $<$ http://www.asser.nl/upload/documents/672011_23350CLEER\%20WP\%202011-2-\%20HOEKSMA.pdf > accessed 18 March 2012.

${ }^{148}$ P-C Müller-Graff, 'Verfassungsziele der EG/EU' in M Dauses (ed), Handbuch des EU-Wirtschaftsrechts (loose-leaf, 27th edition, updated October 2010, CH Beck, 2010), para 84, who stresses that neither the US nor the German constitutions were ever submitted to a plebiscite. 
States have approved the EU Treaties, including the external objectives contained therein. This is nothing less than the expression of a European will to contribute to global governance along the lines provided therein, ie to contribute actively to providing various global public goods such as security or environmentally sustainable prosperity, as well as a global bolstering of the rule of law.

Furthermore, as we have seen, the EU is not alone in this, but is indeed part of a global trend in which democratic constitutions express similar goals for international cooperation, the respect of international law, peaceful resolution of disputes and the spread of human rights. According to Rosenau, 'hierarchy is certainly not a necessary prerequisite to the framing of goals'. ${ }^{149}$ Therefore, rather than looking for a top-down imposition of global principles on the international level, or a single list of goals drawn up by adherents of one or the other IR theory, constitutional documents around the world, as the bottom-up crystallization of stable popular preferences, arguably represent a preferable source. From the selection of documents here, the common denominator for a global 'common ideology' (at least among the democratic polities) to guide global governance can already be seen to emerge. However, a strong emphasis on law as part of such an ideology is still a rather unique feature of EU constitutional law.

\section{Conclusion}

At the outset of this chapter, it was observed that in view of the diverse assessments of the EU's contributions to global governance, there is a great need for stable and justifiable benchmarks. It has been argued that constitutional law can provide exactly that.

Within this constitutional dimension of global governance, a concept inherently based on goals and rules, one can distinguish between the entrenchment of substantive objectives relevant for global governance and constitutional provisions which specifically harness law to frame the pursuit of these goals. We have seen that modern constitutions, including those of the rising powers of a future multi-polar world, are ample providers of substantive objectives. Stressing the importance of law in this context, however, is far from ubiquitous. On the contrary, the post-Lisbon EU Treaties provide both an extensive and sophisticated account of substantive goals as well as a particularly strong emphasis on law in this regard.

Beyond the empirical, it was argued that the particular features pertaining to constitutional law make it a formidable source for framing global governance. Only on the surface did these features appear as problematic. First, instead of overly judicializing the area of foreign affairs, constitutionally entrenching a global governance agenda readjusts the institutional balance and fosters the rule of law internally. It rejects the 'classic' idea of the executive branch acting alone and largely legibus solutus in foreign policy. Where constitutions encourage the development of international law and participation in international organizations, as is the case in the EU, a constitutional foundation for extending the rule of law globally is established. This emphasizes the conception of global governance as both multi-level and multi-actor rule-setting.

Secondly, even though codifying foreign policy objectives into a polity's constitution doubtlessly raises expectations as to the performance of that actor, these cannot be considered as entirely unrealistic and unhelpful. Crucially, many of these objectives concern global public goods, which can be provided only through multilateral cooperation. In view of the many constitutional emphases on the need for international cooperation, a global duty to cooperate towards milieu goals based on constitutional law can be discerned. Here, the Union's experience as a community with common goals based on the rule of law can

149 Rosenau, Governance in the 21st Century, n 16, 14. 
serve as inspiration to foster a global framework regulating effectively and equitably the provision of such goods.

Thirdly, constitutional entrenchment can serve as an important source of legitimacy, of which global governance is in dire need. Where a constitution is the highest law within a democratic community, its codified vision for global governance also forms part of the 'common ideology' of that community. Moreover, given the broad substantive similarities in the democratic constitutions reviewed in this regard, a global basic consensus calling for more active contributions to global governance along these broad lines can be seen to emerge. However, the worldwide promotion of the rule of law, while an important part of the constitutional 'common ideology' of the EU, is not generally shared.

Of course, constitutionally entrenching a particular vision for global governance does not automatically bring this vision to life. Indeed, the challenges facing the EU and the international community as a whole are enormous and make the more ambitious constitutional objectives frequently appear overly audacious. But as was shown, this entrenchment serves to establish democratically legitimated, stable expectations, which also feed into the overall interpretation of a political community's highest laws. It mandates the competent constitutional organs to work and cooperate with others towards these goals. This in itself represents a success. In all these respects, the EU and its primary law stand out. The level of comprehensiveness of the substantive objectives present in the EU Treaties surpasses that of any national constitution. At least as important though is their clear preference for multilateralism, as well as their embrace of law as an essential ingredient of global governance. For the time being, it is in the EU Treaties that the legal dimension of global governance finds its strongest and most vigorous constitutional expression. 